Resources for Reform 



\section{Resources for Reform}

Oil and Neoliberalism in Argentina

Elana Shever 
Stanford University Press

Stanford, California

(C) 2012 by the Board of Trustees of the Leland Stanford Junior University. All rights reserved.

No part of this book may be reproduced or transmitted in any form or by any means, electronic or mechanical, including photocopying and recording, or in any information storage or retrieval system without the prior written permission of Stanford University Press.

Printed in the United States of America on acid-free, archival-quality paper

Library of Congress Cataloging-in-Publication Data

Shever, Elana, author.

Resources for reform : oil and neoliberalism in Argentina / Elana Shever. pages $\mathrm{cm}$

Includes bibliographical references and index.

ISBN 978-0-8047-7839-8 (cloth : alk. paper) — ISBN 978-0-8047-7840-4 (pbk. : alk. paper)

1. Petroleum industry and trade-Political aspects-Argentina. 2. Petroleum industry and trade-Social aspects-Argentina. 3. Neoliberalism-Argentina. 4. Protest movementsArgentina. 5. Kinship-Political aspects-Argentina. 6. Citizenship-Argentina. I. Title. HD9574.A72S47 2012 338.2 '72820982-dc23

\section{3}

Typeset by Bruce Lundquist in 10/14 Minion 
For Jonathan 
